Waldo Vila

\title{
Jerónimo Costa. La exposición de un maestro
}

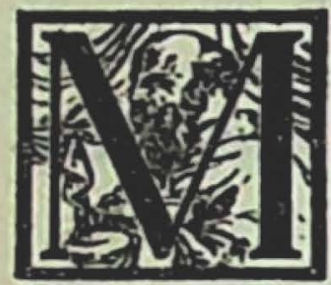

AESTRO de las artes mayores en superación humana y plenitud de una vida lograda de maestro, más allá de la línea de valores superiores humanos. Vanidad, orgullo y envidia, dominados están en este hombre seráfico de vida pura, que parece mirar todo lo que le rodea, como una simple apariencia engañosa. Hunde su mirada en el fondo de sí mismo y alcanza el fondo azul del misterio de la belleza en plenitud. Ajeno a todo exhibicionismo, se escondió para que no pudieran encontrarlo los que le hablaron de la exposición que acaba de efectuar el Ministerio de Educación. Los organizadores de ella, debieron, por lo tanto, recurrir a las colecciones particulares y a los museos.

Una tarde cualquiera, el pintor visitó clandestinamente su propia exposición. Se caló un sombrero hasta los ojos para no ser reconocido y con un gesto aburrido de la mano se borró la cara. Con todo lo descubrieron, fusilándolo de inmediato con el fogonazo implacable de los fotógrafos. La reacción de Costa frente a sus propios cuadros, debieron ser las mismas de aquel personaje de "Enterrado en Vida" del humorista inglés Arnold Benett. Ese tímido incurable, que se supone fuera el propio Turner, el de las diabólicas desapariciones, encarnado por el escritor en el flamante pintor Prym Fall, que se esconde detrás de su mayordomo, o ayuda de cámara, a quien todos 
conocen como su representante en la tierra, porque al maestro nadie lo ha visto nunca en presencia física. Un mal día muere de neumo. nía, el infortunado, como insustituible ayuda de cámara, y el pintor aterrado ante la pregunta severa, sospechas a que el muerto sea el propio Prym Fall, por cuanto reposa en su propio lecho, donde lo había acostado en medio de su desamparo. Se queda mudo y no dice una palabra cuando lo entierran nada menos que en la Abadía de Westminster, bajo el glorioso nombre de Prym Fall. Acude de incógnito a sus funerales y es tal la emoción al saberse un muerto tan ilustre, que no puede contener los sollozos y es expulsado por falta de respeto de aquel sagrado recinto.

Buen Jerónimo Costa, amigo entrañable e inseparable compañero de Arturo Gordon. Llega hasta mí en esta tarde lluviosa en medio del verano, con el caudal mirífico de su pintura angélica. Pintor que ha sido designado erróneamente por algunos críticos, como perteneciente a la famosa generación del trece. Me lo ha confirmado el propio Costa, que perteneció junto con Gordon, Abarca y los hermanos Ortiz de Zárate, a la generación de 1900, que tuvo por maestro a don Pedro Lira, incorporándose años después a la otra, la del número fatídico, comandada por el maestro don Fernando Alvarez de Sotomayor. Jerónimo Costa, en su renuncia total del mundo y de sus vanas pompas, se ha recogido en sí mismo. Una consigna de silencio parece sellarle los labios, un voto de pureza en el alma y el sorbo de agua clara de cada día. Tal vez me reconvenga dulcemente por escribir estas cosas, tal vez tenga como un temblor de lágrimas su voz, cuando me dé las gracias.

En este día sábado triste como de invierno, la lluvia ha repiqueteado toda la noche con sus dedos menudos la desolada canción que prepara mi espíritu, para hablar de esa tristeza indefinible que emana de sus cuadros. Yo lo sabía, suyo era este día nebuloso y de su pintura quería hablar.

Jerónimo Costa, voz pura que rezuma calladamente de su interior, nos trae del tiempo y su distancia, el caudal de esta pintura. En la sordina de los azules plata y grises, bruma dorada de exquisita 
poesía imprecisa, vuelvo a encontrar mis propias palabras para hablar también de Costa una vez más.

Jerónimo Costa, debido posiblemente a su ancestro europeo, sigue muy certeramente el movimiento plástico francés de aquel tiempo, posterior desde luego al de 1900. Dijimos en otra ocasión, de su parentesco espiritual con Millet, sin que esto significara parecido alguno con los paisajes o composiciones del pintor francés. Es más bien una relación sutil, impalpable, con el maestro del "Angelus" ¡Todo quietud y recogimiento religioso, del minuto y la hora!

Hay en sus cuadros un total dorado de tostados y cálidos tonos, como fundidos con el fondo de donde emerge el aura amarillenta de la luz de una vela; aguza su llama, estableciendo la mancha empalidecida de un dulce rostro en penumbra. Mas no debemos engañarnos, bajo esta aparente tranquilidad alienta un alma apasionada y doliente.

El espectador fino lo capta de inmediato, siente el vaho de tristeza indefinible que se desprende de sus cuadros, tanto, que muchos posibles compradores demasiado saludables, preferirían desde luego no tenerlos en sus casas. Tal vez tengan razón, desde sus puntos de vista, en aquello deseable por nuestro público, alimentado desde luego con un arte en latas, por serie, que reparte por todo el mundo con profusión el cine norteamericano, que debe traer consigo, inevitablemente, el consabido happy end con el beso apasionado de la pareja venturosa. La pintura expresa a través del hombre interno, el mundo externo que lo rodea, que es la verdad insobornable del tiempo en que se vive. Costa refiere el abandono y la vida durísima del pintor en un medio brutal e incomprensivo, que vió destruirse a la más brillante generación de pintores, la famosa y trágica del trece, en la que también militó como un joven maestro. Costa, dulce y silencioso, estuvo hombro con hombro en esa falange de artistas. Dice Neruda de ellos: "entre esas cabezas desgranadas por la vida durísima y la solitaria muerte" (1).

(1) Del prólogo del libro próximo a aparecer: Una capitania de pintores, de Waldo Vila. 
Vuelven a la luz de la publicidad los cuadros de Costa, después de largos años de olvida en los museos y en las colecciones privadas. Mi admiración permanece la misma. Siempre es la nota emocionada de quietismo en sus interiores, donde están sus mujeres yacentes y la poesía profunda de su alma callada, que es como una isla sola entre el efectivismo vacío de la época anterior, cuando predominaba la moda de los grandes paisajes de visión panorámica y los cuadros de género, de temática histórica, realizados a la manera de escenas teatralizadas. Por el contrario, los asuntos de este pintor, son de recogimiento e intimidad, y ausente de todos ellos está el efectivismo fácil. Dibujante fino y elegante, busca en una línea de composición el mejor equilibrio de los elementos plásticos. Hay siempre en su obra, como ya lo subrayamos, un contenido poético que la hace especialmente valiosa, más si consideramos que están logradas plásticamente, sin recursos de ningún artificio literario. Es buena pintura de un artista que sabe su oficio a conciencia. Paisajes sin estridencias, de una acordación emotiva más bien sorda, a la vez que de gran fuerza de color. La tarde que se extingue en la hora crepuscularia, es amada por Costa. Un grupo de árboles solitarios, en una variante de tonos azules y violetas, la masa obscura de una casa y las figuras medio inclinadas de mujeres que, con sus rebozos negros, caminan bajo el peso de la tarde que se amustia. El interior de una habitación sola, de muebles familiares, sobre una cómoda, como la que tenía mi madre, hay una imagen entre cándidas flores, ante la que arden los cirios votivos, "La Manda". Ofrenda de un alma sencilla que debió arder como la llama de esos cirios. "El Nocturno", de una mortecina luz de farol, destaca la mancha obscura de un coche de posta, aquellos viejos postinos de nuestra infancia, de maravilloso dibujo, con los viejos caballos cansados de lento paso. En otra tela, son los grises azules y plata del parque invernal, estilizados árboles, dibujados en el croquis más viviente del apunte mejor logrado. Todas sus telas son como el mundo sin historia de pequeñas vidas, de cosas y seres amados, ya seguramente extinguidos para siempre. En los 
cuadros de tono menor de Costa, hay como una presencia invisible de labios tristes y cerrados, que impone el silencio.

Los jóvenes de la actual generación me preguntaban por la existencia de este esquivo pintor, casi el único de aquellas generaciones famosas que permanece y trabaja. Les hablé de la pura existencia de este hombre, que nunca logró salir de Chile. Algunos reveses de fortuna le hicieron perder sus ahorros laboriosamente ganados. Esto lo volvió retraído y misántropo. Cuando debería tener un merecido descanso y no menos merecidos honores, se vió obligado a trabajar diariamente en labores no muy gratas para un artista. Hoy en día, alejado del bullicio y de toda vanagloria, tiene la cabeza blanca y los tristes ojos más bondadosos.

Pienso en ese azar de los premios, que van a dar a veces a donde menos se espera, tanto que a veces el propio agraciado resulta el más sorprendido. Le confesaba un amigo escritor al poeta Carlos Préndez Saldías, que él continuaría escribiendo cuentos, novelas y teatro, por si acaso le tocaba el premio de química instituído por la Universidad. Yo también espero, que por extraños designios, mi buen Jerónimo Costa reciba en su voluntario destierro, como un capricho de la fortuna, el Premio Nacional de Pintura. Pueden defenderse todas las posiciones, aún las más absurdas, agrega el comentarista citado, pero yo creo que en el caso de Jerónimo Costa, nadie podría discutir sus altos méritos, que cumplen hasta la saciedad los que el reglamento para otorgar el consabido premio establece. Una vocación y una labor sostenida. Todavía hay más, nuestro candidato pertenece junto con Gordon, Abarca y Pedro Luna, como lo hemos establecido en el presente ensayo, a la generación del 1900, continúa después en la del trece y aun en la época actual nos asombra con su reciente exposición. A sus amigos y compañeros ya muertos no se les dió nunca la recompensa merecida, hagamos justicia alguna vez a todos ellos en Costa, otorgándole el Premio Nacional que merecieron más allá de toda justicia. 